\title{
The impact of resolving the Rossby radius at mid-latitudes in the ocean: results from a high-resolution version of the Met Office GC2 coupled model
}

\author{
Helene T. Hewitt ${ }^{1}$, Malcolm J. Roberts ${ }^{1}$, Pat Hyder ${ }^{1}$, Tim Graham ${ }^{1}$, Jamie Rae ${ }^{1}$, Stephen E. Belcher ${ }^{1}$, \\ Romain Bourdallé-Badie $^{2}$, Dan Copsey ${ }^{1}$, Andrew Coward ${ }^{3}$, Catherine Guiavarch $^{1}$, Chris Harris ${ }^{1}$, Richard Hill ${ }^{1}$, \\ Joël J.-M. Hirschi ${ }^{3}$, Gurvan Madec ${ }^{3,4}$, Matthew S. Mizielinski ${ }^{1}$, Erica Neininger ${ }^{1}$, Adrian L. New ${ }^{3}$, \\ Jean-Christophe Rioual ${ }^{1}$, Bablu Sinha ${ }^{3}$, David Storkey ${ }^{1}$, Ann Shelly ${ }^{1, a}$, Livia Thorpe ${ }^{1}$, and Richard A. Wood ${ }^{1}$ \\ ${ }^{1}$ Met Office, Exeter, UK \\ ${ }^{2}$ Mercator Océan, Toulouse, France \\ ${ }^{3}$ National Oceanography Centre, Southampton, UK \\ ${ }^{4}$ IPSL, Paris, France \\ ${ }^{a}$ now at: Cumulus, City Financial Investment Company Limited, London EC4R 1EB, UK
}

Correspondence to: Helene T. Hewitt (helene.hewitt@metoffice.gov.uk)

Received: 11 April 2016 - Published in Geosci. Model Dev. Discuss.: 19 April 2016

Revised: 20 September 2016 - Accepted: 25 September 2016 - Published: 13 October 2016

\begin{abstract}
There is mounting evidence that resolving mesoscale eddies and western boundary currents as well as topographically controlled flows can play an important role in air-sea interaction associated with vertical and lateral transports of heat and salt. Here we describe the development of the Met Office Global Coupled Model version 2 (GC2) with increased resolution relative to the standard model: the ocean resolution is increased from $1 / 4$ to $1 / 12^{\circ}$ (28 to $9 \mathrm{~km}$ at the Equator), the atmosphere resolution increased from $60 \mathrm{~km}$ (N216) to $25 \mathrm{~km}$ (N512) and the coupling period reduced from 3 hourly to hourly. The technical developments that were required to build a version of the model at higher resolution are described as well as results from a 20-year simulation. The results demonstrate the key role played by the enhanced resolution of the ocean model: reduced sea surface temperature (SST) biases, improved ocean heat transports, deeper and stronger overturning circulation and a stronger Antarctic Circumpolar Current. Our results suggest that the improvements seen here require high resolution in both atmosphere and ocean components as well as high-frequency coupling. These results add to the body of evidence suggesting that ocean resolution is an important consideration when developing coupled models for weather and climate applications.
\end{abstract}

\section{Introduction}

On the scale of the Rossby radius, the ocean is rich with mesoscale eddies (Chelton et al., 2011) and oceanic fronts. There is mounting evidence from satellite observations that mesoscale features in the sea surface temperature (SST) field can drive comparable variations in atmospheric winds and surface fluxes (Chelton and Xie, 2010; Frenger et al., 2013). While at the basin scale, observed correlations between SST and surface winds are negatively correlated, indicating that the atmosphere is driving the ocean, in frontal regions with high mesoscale activity, such as those associated with western boundary currents, SST and surface winds are positively correlated, implying that the ocean is driving the atmosphere (Bryan et al., 2010). While the primary response to SST takes place in the atmospheric boundary layer (Chelton and Xie, 2010), there is also evidence that divergence of surface winds may give rise to vertical motions, which may penetrate high into the troposphere affecting storm tracks and clouds (e.g., Minobe et al., 2008; Sheldon and Czaja, 2014). Of particular note is the intense rain band in the North Atlantic that follows the path of the Gulf Stream/North Atlantic Current.

The recent CMIP5 ocean models have a horizontal resolution of between 1 and $1 / 4^{\circ}$. However, with a resolution of $28 \mathrm{~km}$ at the Equator down to $6 \mathrm{~km}$ in the Cana- 
dian archipelago (due to the tripolar grid), even $1 / 4^{\circ}$ remains insufficient to resolve mesoscale eddies that have a typical scale of $50 \mathrm{~km}$ in the deep ocean at mid-latitudes (Hallberg, 2013). Several climate modelling groups have now built global coupled models with an "eddy-resolving" component (e.g., McClean et al., 2011; Bryan et al., 2010; Delworth et al., 2012; Small et al., 2014; Griffies et al., 2015). In this paper, we describe results from coupling the $1 / 12^{\circ}$ ocean model (ORCA12) produced by the Drakkar group (Marzocchi et al., 2015; Deshayes et al., 2013; Tréguier et al., 2012) to a $25 \mathrm{~km}$ (N512) resolution version of the Met Office Unified Model (MetUM) atmosphere. This is the first version of the HadGEM3/Global Coupled (GC) series (Hewitt et al., 2011; Williams et al., 2015) to resolve the Rossby radius in the ocean at mid-latitudes (with a resolution of $9 \mathrm{~km}$ at the Equator down to $2 \mathrm{~km}$ in the Canadian archipelago) and the first coupled experiment with the NEMO (Nucleus for European Modelling of the Ocean) ORCA12 ocean configuration. The development of a global coupled model with atmosphere and ocean components of this resolution, as well as hourly coupling, is the current state of the art for global climate modelling.

Evidence from forced ocean simulations demonstrates that resolution enables a more realistic representation of both eddy kinetic energy (Hurlburt et al., 2009; Griffies et al., 2015), narrow boundary currents (e.g. Marzocchi et al., 2015) and representation of complex topography, in particular the sills that connect ocean basins (e.g. improved overflows in the VIKING model at $1 / 20^{\circ}$ resolution; Behrens, 2013). In this paper we investigate how ocean resolution drives large-scale changes not only in the ocean but also in the climate system. Changes in the ocean circulation could be important both for present and future climate; for example, in an ocean-only model with a simple domain, Zhang and Vallis (2013) showed that the changes in mean circulation due to eddy-resolving resolution can affect the net ocean heat uptake under global warming scenarios.

In this paper, the model is described in Sect. 2. Our results (Sect. 3) describe the relative impact of the three changes to the model; ocean resolution, atmosphere resolution and coupling frequency. Finally, in Sect. 4 we summarize and discuss the results.

\section{Model description}

The development of the high-resolution coupled climate model is based on the Met Office Global Coupled model version 2 (GC2; Williams et al., 2015). GC2 is comprised of the MetUM (GA6) atmosphere, the JULES land surface model (Best et al., 2011; GL6), the NEMO ocean model (Madec, 2014; GO5, Megann et al., 2014) and the Los Alamos CICE sea ice model (Hunke and Lipscomb, 2010; GSI6, Rae et al., 2015). The standard configuration for GC2 has a $60 \mathrm{~km}$ resolution atmosphere coupled to $1 / 4^{\circ}(28 \mathrm{~km}$ at the Equator re- ducing polewards) ocean (N216-ORCA025) with coupling between the components (as described in Hewitt et al., 2011) every $3 \mathrm{~h}$. GA6 has 85 vertical levels while GO5 has 75 vertical levels with $1 \mathrm{~m}$ resolution in the top $10 \mathrm{~m}$ of the ocean (Megann et al., 2014). Although vertical resolution is not explored here, we include details of the vertical levels in Appendix A.

In addition to GC2, this paper describes three modified versions of GC2 with increased atmosphere resolution, increased coupling frequency and increased ocean resolution. The different model experiments are described below and summarized in Table 1.

GC2 has been run with a high $25 \mathrm{~km}$ (N512) atmosphere resolution and the standard (ORCA025) resolution ocean, and we will refer to this as GC2-N512. The scientific differences between N216 and N512 are minimal, as described in Walters et al. (2016), and are principally associated with the time step (modified from 15 to $10 \mathrm{~min}$ ) and the resolution of the external boundary conditions such as the orography.

To facilitate direct scientific comparison with the $1 / 12^{\circ}$ ORCA12 (9 km at the Equator reducing polewards) configuration of NEMO, which was developed using NEMO v3.5 rather than 3.4 (Marzocchi et al., 2015), a modified configuration of $\mathrm{GC} 2$, referred to here for convenience as GC2.1, was developed. The key scientific and technical changes made to GC2.1 are

- a reduction in the coupling period from 3 hourly to hourly;

- an upgrade to the non-linear free surface scheme rather than the linear-free surface;

- a small reduction in the ocean time step from 1350 to 1200 s (to accommodate hourly coupling);

- small changes associated with river outflows, outflows prescribed over $15 \mathrm{~m}$ rather than $10 \mathrm{~m}$ with an enhanced vertical mixing in the outflow region of $1 \times 10^{-3}$ rather than $2 \times 10^{-3} \mathrm{~m}^{2} \mathrm{~s}^{-1}$;

- an upgrade of the sea ice model from CICE4 to CICE5 (Hunke et al., 2015); for technical reasons and the science of the sea ice configuration remains unchanged.

The reduction of the coupling period in GC2.1 did not lead to coupled ocean-sea ice instabilities as described by Hallberg (2014).

To assess the impact of ocean resolution, a traceable GC2.1 configuration with ORCA12 was then built (further technical details and model performance issues are discussed in Appendix B). We chose to increase the atmosphere resolution to N512 in order to maintain a similar ratio of atmosphere to ocean grids. We will refer to this configuration as GC2.1-N512O12 (i.e., increased atmosphere and ocean resolution).

The differences between ORCA025 and ORCA12 in GC2.1 are 
Table 1. Coupled models used in this paper.

\begin{tabular}{lll}
\hline Model & $\begin{array}{l}\text { Horizontal } \\
\text { resolution }\end{array}$ & $\begin{array}{l}\text { Coupling } \\
\text { frequency }\end{array}$ \\
\hline GC2 (Williams et al., 2015) & N216-ORCA025 & 3 hourly \\
GC2-N512 & N512-ORCA025 & 3 hourly \\
GC2.1 (this paper) & N216-ORCA025 & 1 hourly \\
GC2.1-N512O12 & N512-ORCA12 & 1 hourly \\
\hline
\end{tabular}

- a reduction in the time step from 1200 to $240 \mathrm{~s}$

- a reduction in the isoneutral tracer diffusion from 300 to $125 \mathrm{~m}^{2} \mathrm{~s}^{-1}$

- a reduction in the bilaplacian viscosity from $1.5 \times 10^{11}$ to $1.25 \times 10^{10} \mathrm{~m}^{2} \mathrm{~s}^{-1}$.

We note here that the parameter settings in GC2.1-N512O12 have not been tuned for the coupled model; the model was run using the majority of parameter settings from the forced ocean-only ORCA12 runs of Marzocchi et al. (2015). While reducing the isoneutral tracer diffusivity is consistent with the increase in resolution, we note that results may have some sensitivity to its magnitude. Experiments to investigate the impact of this parameter in GC2 were not performed but will be pursued in future work with GC3 (the next version of the coupled model).

GC2.1-N512O12 was found to be very sensitive to features that had not proved to be a problem in previous oceanonly integrations (e.g., Marzocchi et al., 2015). For example, the model became unstable on the east coast of the UK every 6-12 months of simulation due to extreme values in the velocity field, likely due to the lack of tidal dissipation in the model, which is very important in this region. The model was restarted from these failures with a small random perturbation to the atmosphere temperature field in a similar way to treatment of "grid-point instabilities" previously seen in atmosphere models (e.g., Mizielinski et al., 2014). The underlying problem with this unstable ocean point will be addressed in future developments of the ORCA12 configuration.

The GC2 and GC2.1 experiments were run for 20 years with fixed atmospheric radiative forcing representative of the present day (with greenhouse gas and aerosol values for the year 2000). All experiments were initialized in the following way:

- Atmosphere: N216 and N512 are both from September year 18 of the model state of a previous N512 GA6 (Walters et al., 2016) forced atmosphere integration with forcing representative of the year 2000 , so that the land surface properties are at quasi-equilibrium.

- Ocean: 5-year September mean temperature and salinity from the EN3 observational data set (Ingleby and
Huddleston, 2007) centred on 2006 with velocities initialized to zero;

- Sea ice: 20-year September mean from a HadGEM1 (Johns et al., 2006) experiment represents of a period centred on 1978.

- The latter two are the standard method for initialization of "present-day" coupled simulations at the Met Office.

The choice of the most appropriate ratio between ocean and atmosphere resolution remains an open research question worthy of further study. Short (2-year) integrations using both higher and lower atmosphere resolutions coupled to ORCA12 were completed, although due to the short length of the integrations, they are not analysed here. In particular, a configuration using an N768 (17 km) atmosphere led to a marked increase in the frequency of the type of model instabilities described earlier (from 1-2 per year to 5-6 per year).

\section{Impact of model resolution on surface properties, heat transport and ocean circulation}

The results shown in this section are derived from 20-year simulations of the four experiments described in Table 1, initialized and forced in an identical way.

\subsection{Surface properties}

The pattern of large-scale biases in SST fields in Hadley Centre coupled climate models have remained largely unchanged since the models first ran without flux correction (e.g., Gordon et al., 2000); the large-scale biases exhibit warming in the Southern Ocean, cooling in the North Pacific and North Atlantic and warming in upwelling/stratocumulus regions off the western coasts of South America and Africa. Many of these biases are also very common in other models (e.g. Small et al., 2014). In contrast to the pattern, the magnitude of the SST biases has changed between model versions; in particular, comparing GC2 and HadGEM2-AO (Fig. 1 of Williams et al., 2015) shows that the magnitude of the Northern Hemisphere cooling was reduced in GC2 while the magnitude of the Southern Ocean warming was approximately doubled. Reducing SST biases in the Southern Ocean is the topic of ongoing work.

The time series of the global mean top-of-atmosphere (TOA) radiation imbalance in the four models (Fig. 1a) shows that the experiments with high (N512) atmosphere resolution have TOA radiation imbalances that are generally higher at the start of the experiments. However, after 20 years all the experiments are starting to converge to a similar net TOA, as the shortwave and long-wave components adjust. Although the TOA-SST relationship is poorly defined (since the TOA imbalance is related to the rate of change of net ocean heat content; Palmer and McNeall, 2014), the 

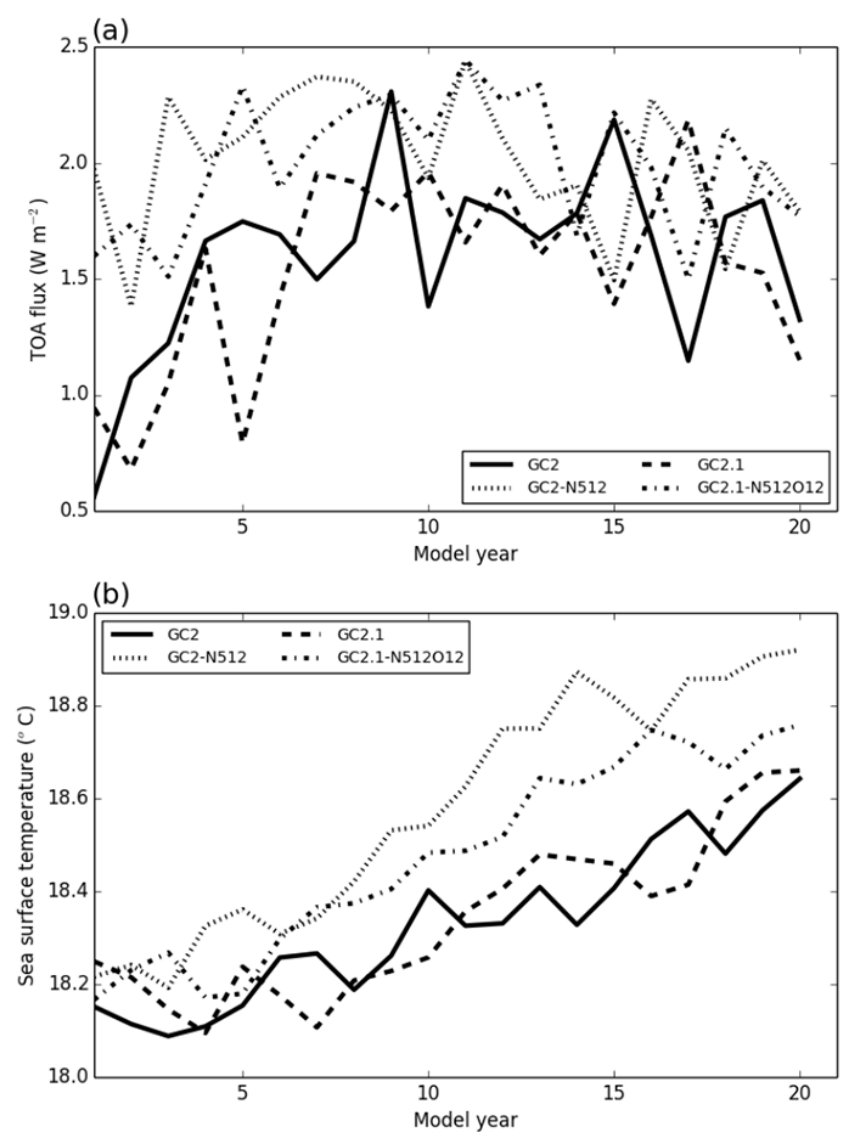

Figure 1. Time series of (a) net TOA and (b) global mean SST from GC2, GC2-N512, GC2.1 and GC2.1-N512O12.

integrated effect of the higher net TOA in the N512 experiments can be seen in the time series of the global mean SST (Fig. 1b) with GC2-N512 and GC2.1-N512O12 having higher global mean SSTs.

In spite of the differences in global mean SST, major changes to the pattern and magnitude of SST biases are only seen with both high atmosphere and ocean resolution (Fig. 2). In GC2.1-N512O12, the large-scale underlying SST biases are reduced relative to GC2 and GC2.1 (Fig. 3): the warm bias in the Southern Ocean, cold bias in North Atlantic and North Pacific and warm biases in stratocumulus regions. Similar reductions in SST biases with high atmosphere and ocean resolution were also seen in Small et al. (2014). The increase in ocean resolution is key to this improvement; when only atmosphere resolution is increased (compare Fig. 2a and b), there is only a small reduction in the warm bias associated with stratocumulus regions (west of South America and Africa), whereas increased coupling frequency (compare Fig. 2a and c) shows only minor changes in SST biases.

In GC2 there is a cold bias in the North Atlantic subpolar gyre (SPG), Greenland-Iceland-Norwegian (GIN) seas and the Arctic. GC2.1-N512O12 shows a warming of several degrees in the SPG and GIN seas relative to GC2 (see reduced cold bias in Fig. 2d) and a very large warming in the central Arctic. The warming in the central Arctic is associated with a warming in the subpolar gyre, enhanced northward heat transport into the Arctic and melting back of the sea ice edge in the Arctic (see below).

Resolution appears to have less of an impact on sea surface salinity (SSS; Fig. 4). Nevertheless, there are reductions in high salinity biases in the Indian Ocean and the Pacific (in particular, in the salinity maximum in the subtropical gyre of the South Pacific) as well as reductions in the Arctic biases (although these are very sensitive to the distribution of sea ice).

\subsection{Sea ice}

The changes to the SST also affect sea ice distribution in both hemispheres. The seasonal cycle of ice extent in the Arctic (Fig. 5a) shows that the warm SSTs in GC2.1-N512O12 at high northern latitudes reduce the ice extent throughout the year. The March ice concentrations in the Arctic (Fig. 6) clearly demonstrate that the impact on the sea ice is concentrated in the GIN seas with the sea ice edge in GC2.1N512O12 much further north than seen in GC2 with the edge being north of Spitzbergen and into the Barents Sea.

In comparison, the reduction in the warm bias in the Southern Hemisphere leads to only modest increases in the total sea ice extent (Fig. 5b); the overall warming bias associated with the lack of super-cooled liquid clouds (BodasSalcedo et al., 2014, 2016) still dominates the melting of sea ice. The small increase in sea ice extent is very inhomogeneous; indeed, some regions in the Southern Ocean such as the Weddell Sea actually show reductions in sea ice extent in GC2.1-N512O12 (Fig. 6). The reduction in the Weddell Sea is associated with the formation of polynyas in that region (see below).

\subsection{Sub-surface ocean drifts}

Conservation of heat within the climate system implies that the net heat uptake by the ocean should nearly balance the net radiative imbalance at the TOA. GC2.1-N512O12 has the highest TOA imbalance of the four models (Table 2) and therefore will have the greatest net heat uptake. Both models with increased atmosphere resolution (GC2-N512 and GC2.1-N512O12) have a higher TOA imbalance than the models with lower atmosphere resolution (GC2 and GC2.1).

The global temperature profiles (Fig. 7a) show that GC2N512 and GC2.1-N512O12 do indeed have greater increases in temperature as a function of depth than either of the lowresolution models (GC2 and GC2.1), which is consistent with the higher TOA imbalance. The main difference between GC2-N512 and GC2.1-N512O12 is that the increase in heat uptake extends deeper in GC2.1-N512O12. This difference is also apparent in the global mean SST anomaly (Table 2); the SST anomaly for years 11-20 in GC2.1-N512O12 
Table 2. Key metrics from years 11 to 20 of the experiments and observations. TOA observations from CERES/EBAF for years 2000-2010. Global mean SST error (compared to Reynolds OI). Overflows are calculated as southward flow across the Greenland-Iceland-Scotland ridge below density of $27.8 \mathrm{~kg} \mathrm{~m}^{-3}$ and the standard deviation is shown in brackets.

\begin{tabular}{lrrrrr}
\hline Model & $\begin{array}{r}\text { Net TOA } \\
\left(\mathrm{W} \mathrm{m}^{-2}\right)\end{array}$ & $\begin{array}{r}\text { Global mean } \\
\text { SST error (K) }\end{array}$ & $\begin{array}{r}\text { Maximum } \\
\text { overturning } \\
30^{\circ} \mathrm{S}(\mathrm{Sv})\end{array}$ & $\begin{array}{r}\text { Maximum } \\
\text { overturning } \\
24^{\circ} \mathrm{N}(\mathrm{Sv})\end{array}$ & $\begin{array}{r}\text { Net transport from } \\
\text { overflows (Sv) }\end{array}$ \\
\hline Observations & 0.85 & & & & \\
GC2 & 1.61 & 0.25 & 13.7 & 14.6 & $4.0(0.24)$ \\
GC2-N512 & 1.79 & 0.60 & 14.3 & 14.9 & $3.9(0.28)$ \\
GC2.1 & 1.64 & 0.29 & 14.3 & 16.4 & $4.7(0.26)$ \\
GC2.1-N512O12 & 2.02 & 0.44 & 17.5 & 17.7 & $5.9(0.42)$ \\
\hline
\end{tabular}

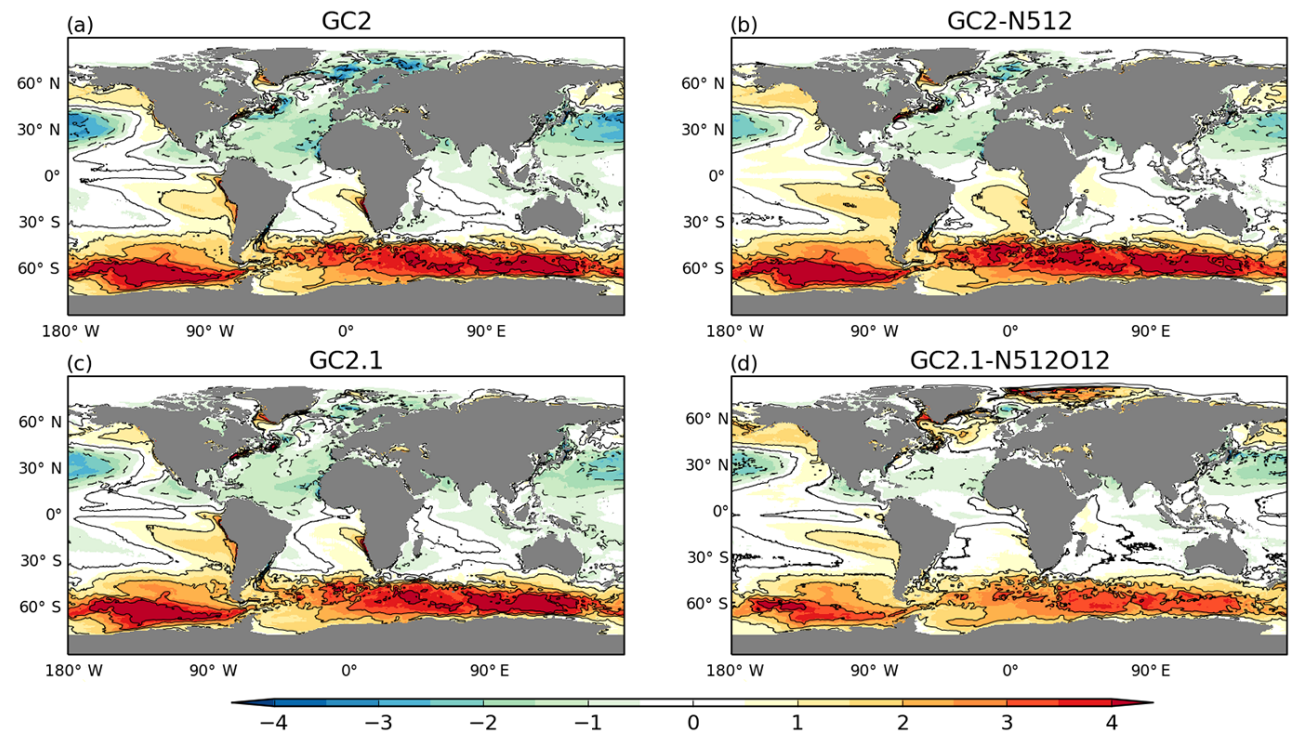

Figure 2. Differences between modelled SST from years 11 to 20 and observed SST from HadISST ( $\left.{ }^{\circ} \mathrm{C}\right)$ for (a) GC2, (b) GC2-N512, (c) GC2.1 and (d) GC2.1-N512O12.

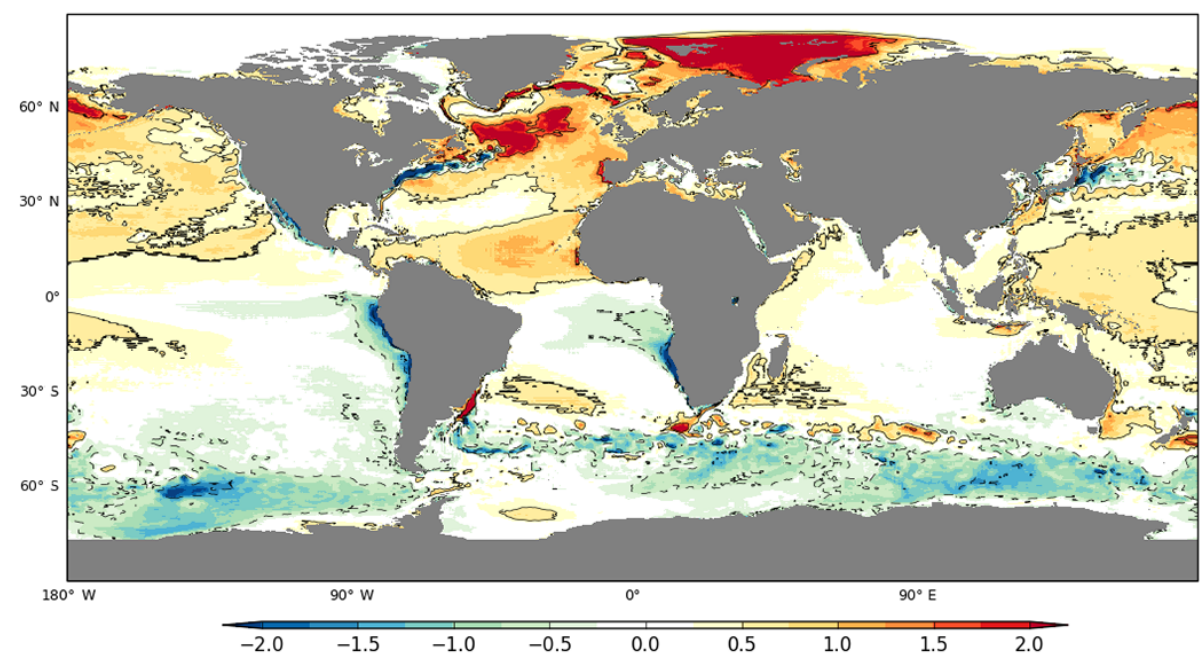

Figure 3. SST difference $\left({ }^{\circ} \mathrm{C}\right)$ for years $11-20$ between GC2.1-N512O12 and GC2.1 


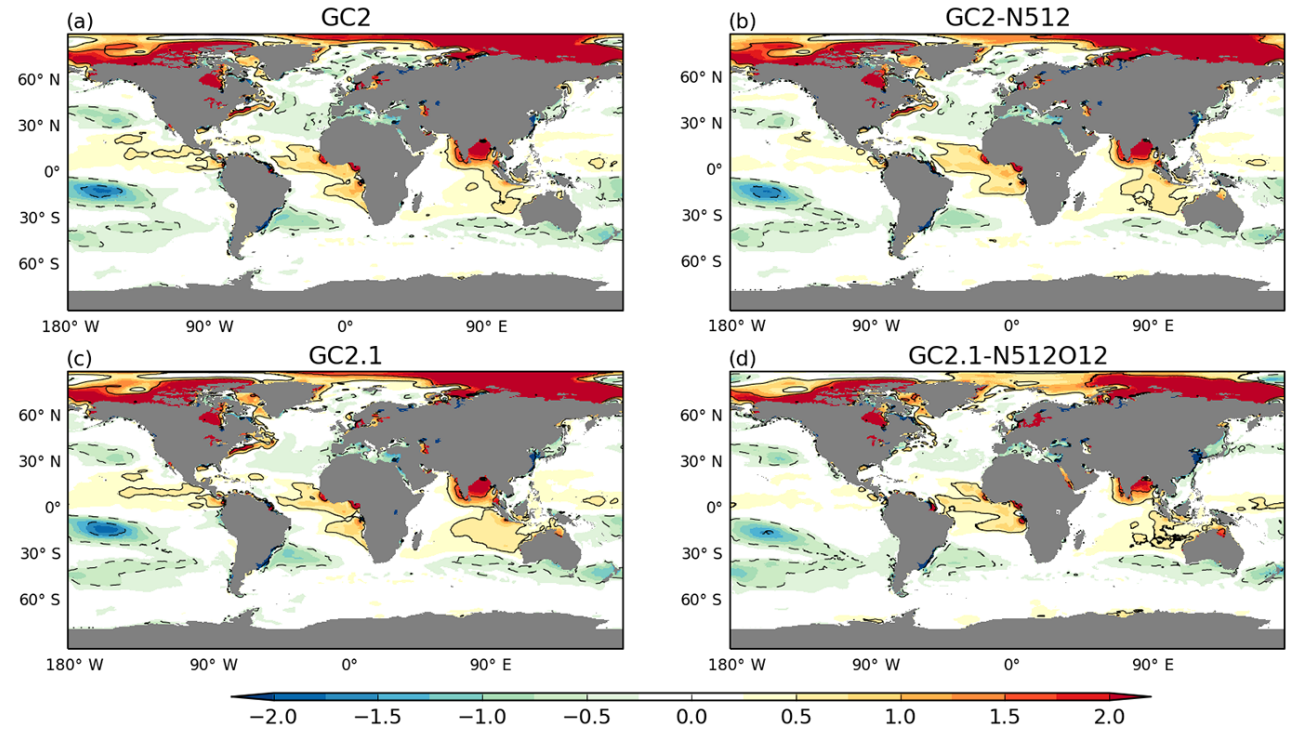

Figure 4. Differences between modelled SSS from years 11 to 20 and observed SSS from EN4 (psu) for (a) GC2, (b) GC2-N512, (c) GC2.1 and (d) GC2.1-N512O12.

is $0.44 \mathrm{~K}$ compared with $0.60 \mathrm{~K}$ in $\mathrm{GC} 2-\mathrm{N} 512$, while the TOA imbalance is 2.02 and $1.79 \mathrm{~W} \mathrm{~m}^{-2}$ respectively. This shows that the ORCA12 version of the model is able to transport heat to depth more effectively.

An increase in heat uptake in GC2.1-N512O12 relative to GC2-N512 is unexpected when considering the results of Griffies et al. (2015). Griffies et al. (2015) showed that an increase in eddy activity produces upward eddy transport with a net effect of reduced heat uptake. Our results do not show a similar result suggesting that either the mean circulation is more effectively transporting heat downwards (which is consistent with an increased overturning circulation) or perhaps that there is an increase in spurious diapycnal mixing. Producing a budget analysis in the future would help to address this issue.

The distribution of the subsurface temperature changes varies depending on the latitudinal range. South of $30^{\circ} \mathrm{S}$ (Fig. 7b), near-surface warming is reduced in GC2.1$\mathrm{N} 512 \mathrm{O} 12$ relative to the other models. In the tropics $\left(30^{\circ} \mathrm{S}-\right.$ $30^{\circ} \mathrm{N}$; Fig. 7c), GC2.1-N512O12 shows increased warming shallower than $500 \mathrm{~m}$ relative to the low-resolution models but reduced relative to GC2-N512. The tropics also show increased warming at depth in GC2.1-N512O12. The largest increase in near-surface temperatures in GC2.1-N512O12 relative to the other models occurs north of $30^{\circ} \mathrm{N}$ (Fig. 7d) with the surface warming displacing a cold bias deeper in the water column. The warming is particularly concentrated north of $65^{\circ} \mathrm{N}$ (Fig. 7e) where it has previously been shown that Arctic sea ice melts back.

Drifts in sub-surface salinity show that GC2.1-N512O12 generally has larger salinity drifts between 500 and $1000 \mathrm{~m}$ (Fig. 8a), which is largely associated with the region south of $30^{\circ} \mathrm{S}$ (Fig. 8b). In the Northern Hemisphere, drifts in salinity between 1000 and $2000 \mathrm{~m}$ are also more pronounced in GC2.1-N512O12 than the other models (Fig. 8d). In contrast, large fresh biases north of $65^{\circ} \mathrm{N}$ in most of the models is much reduced in GC2.1-N512O12 (Fig. 8e). Understanding salinity drifts and their relationship to freshwater forcing is complex (eg, Pardaens et al., 2003) and this aspect of the model performance will require further investigation.

\subsection{Mixed layer depths}

In general over the open oceans, the mixed layer depths ${ }^{1}$ (Fig. 6) are very similar across the different models and it is in the deep water formation regions where we see interhemispheric changes. Winter mixed layers in the Northern Hemisphere in GC2.1-N512O12 show a reduction in the North Atlantic subpolar gyre. Most notably, in GC2.1N512O12 deep mixed layers are less extensive south of Greenland than in GC2 and are confined to the centre of the Labrador Sea. Similar changes in Labrador Sea deep convection have been seen in sensitivity experiments when overflow properties are improved (Graham et al., 2016). The deeper mixed layers in the Arctic in GC2.1-N512O12 are consistent with warmer SSTs and reduced sea ice extent in that region exposing open water.

The similarity of the mixed layer depths across the Southern Ocean demonstrate that it is not changes to the mixed layer depths that lead to a reduction in the Southern Ocean warm bias. As mentioned in the previous section, in the Weddell Sea, GC2.1-N512O12 has very deep mixed layers (max-

\footnotetext{
${ }^{1}$ Mixed layer depth is calculated as the depth at which density changes by $0.01 \mathrm{~kg} \mathrm{~m}^{-3}$ relative to the density at $10 \mathrm{~m}$
} 
(a)

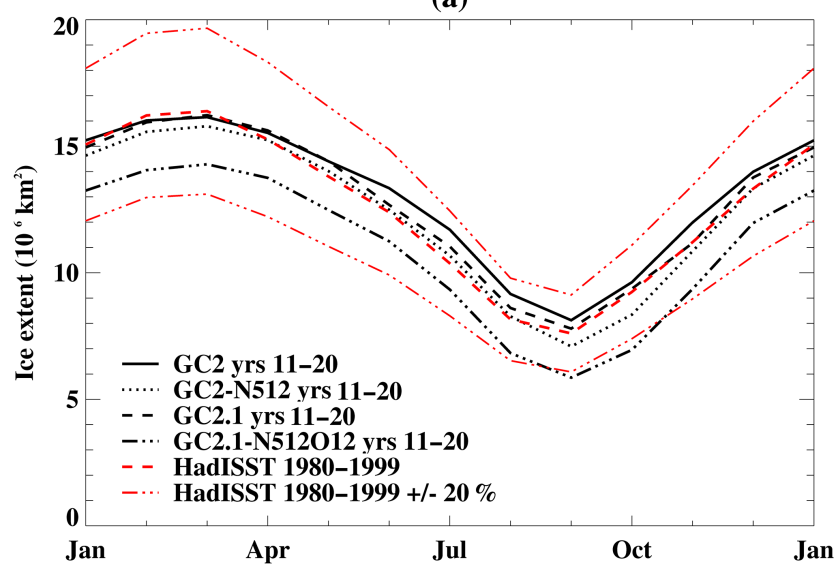

(b)

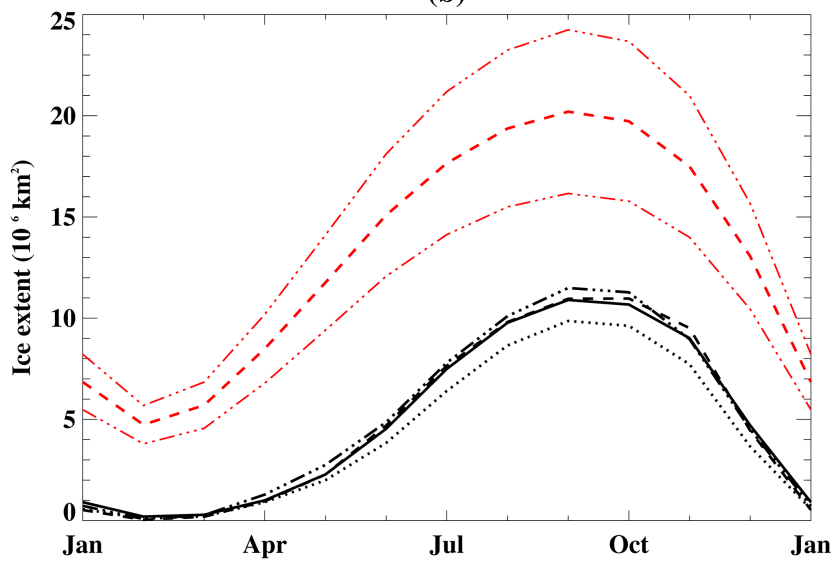

Figure 5. Seasonal cycle of sea ice extent in (a) Northern and (b) Southern hemispheres for years 11-20 compared against HadISST 1980-1999 and with $\pm 20 \%$ error bars denoted.

imum of $800 \mathrm{~m}$ in the decadal mean) linked to the formation of polynyas. Polynya formation varies both spatially and on an interannual basis over the last 9 years of the simulation (Fig. 9); the polynya first appears in year 12 and persists for 5 years before disappearing, starting to re-emerge in year 18 and reaching a depth of $2070 \mathrm{~m}$ in year 20 . The appearance of the polynya in this decade explains the lack of increase of sea ice extent in that region (as seen in Fig. 6). Deeper winter mixed layers in GC2.1-N512O12 are also evident through the mid-latitudes in the formation zones for Sub-Antarctic Mode Waters and Antarctic Intermediate Waters. These could be due to the reduced warm bias (cooler SSTs) in these regions (Fig. 2).

\subsection{Ocean circulation}

The improvements seen in the large-scale SST biases with high atmosphere and ocean resolution (Fig. 3) represent an overall improvement in the model simulation with warming in the Northern Hemisphere and cooling in the Southern

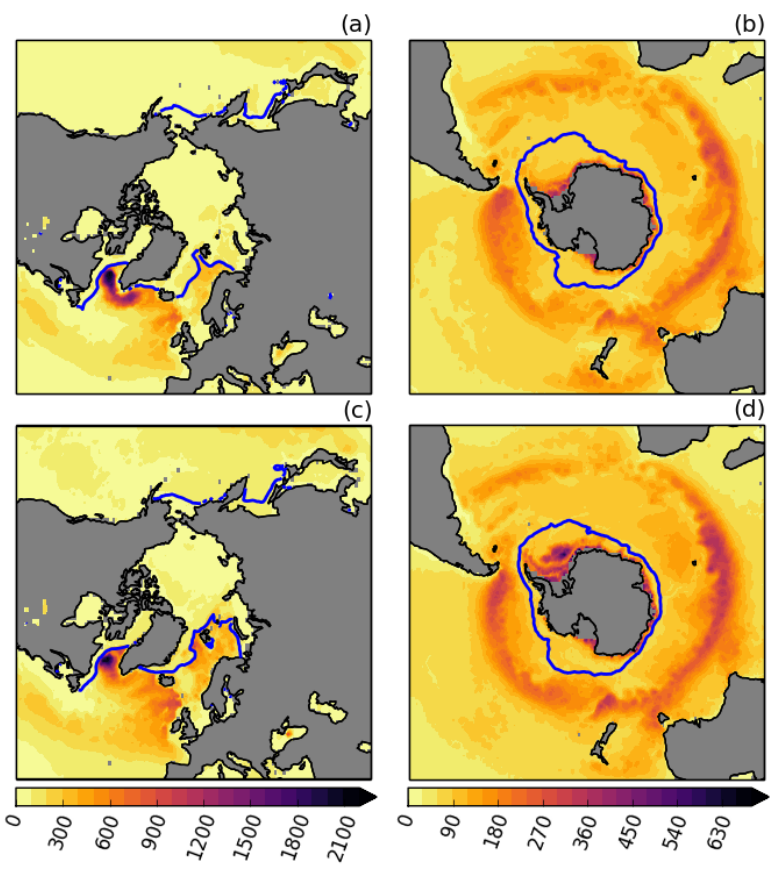

Figure 6. Mean March Northern Hemisphere winter mixed layer depth $(\mathrm{m})$ and sea ice edge and mean September Southern Hemisphere winter mixed layer depth (m) and sea ice edge for years 1120 for GC2 (a, b) and GC2.1-N512O12 (c, d). The sea ice edge (marked in blue) is based on a threshold of $15 \%$ ice concentration.

Hemisphere. This pattern is reminiscent of inter-hemispheric modes that occur as a result of changes in the large-scale thermohaline circulation (Vellinga and $\mathrm{Wu}, 2004$ ). The meridional overturning at $24^{\circ} \mathrm{N}$ in our simulations increases by $1.8 \mathrm{~Sv}$ in GC2.1 and in GC2.1-N512O12 by a further $1.3 \mathrm{~Sv}$ (Table 2 ). At $30^{\circ} \mathrm{S}$, a change of approximately $3 \mathrm{~Sv}$ is only seen in GC2.1-N512O12. The enhanced meridional overturning is therefore attributed to the increased ocean resolution in combination with the increased coupling frequency. The changes in the meridional overturning circulation (Fig. 10) are dominated by changes in the cell associated with North Atlantic Deep Water (NADW) with changes extending into the Southern Hemisphere. Examination of the overturning in density space would further support this analysis but this was not possible with the diagnostics available from this simulation and will be addressed in future simulations.

At the northern end of the NADW cell, we see increases in the volume flux of dense overflows between the GIN seas and the Atlantic (Table 2) that are consistent with the NADW cell being strengthened both by the GIN seas sources and better representation of sills. The volume flux of overflow waters across Denmark Strait generally reduces fairly rapidly in ORCA025 runs (Fig. 11a) but in GC2.1-N512O12 the overflow remains closer to the observed value of 2.93.7 Sv (Dickson and Brown, 1994; Macrander et al., 2005; 

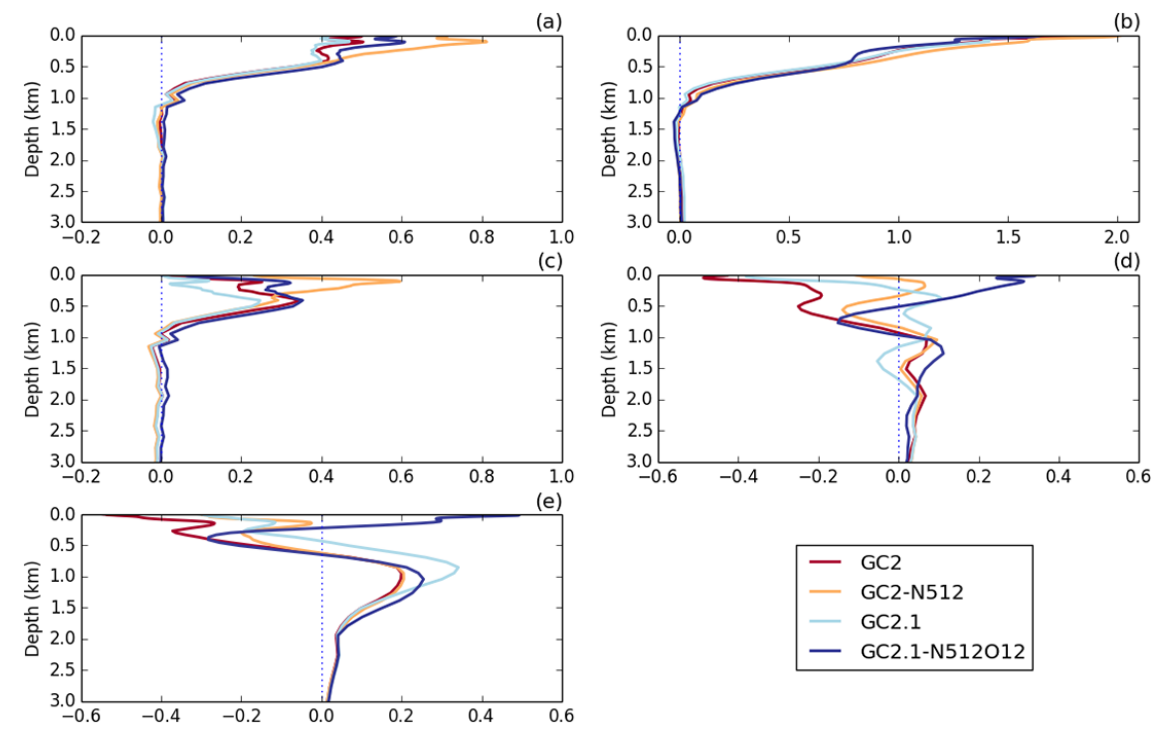

Figure 7. Area-weighted mean temperature difference (years 11-20 minus year $1{ }^{\circ}{ }^{\circ} \mathrm{C}$ ) for GC2, GC2-N512, GC2.1 and GC2.1-N512O12 for (a) global, (b) $90-30^{\circ} \mathrm{S}$, (c) $30^{\circ} \mathrm{S}-30^{\circ} \mathrm{N}$, (d) $30-90^{\circ} \mathrm{N}$ and (e) $65-90^{\circ} \mathrm{N}$. Note the range on the $x$ axis is equal in all panels except panel (b). The vertical axis denotes depth $(\mathrm{m})$.
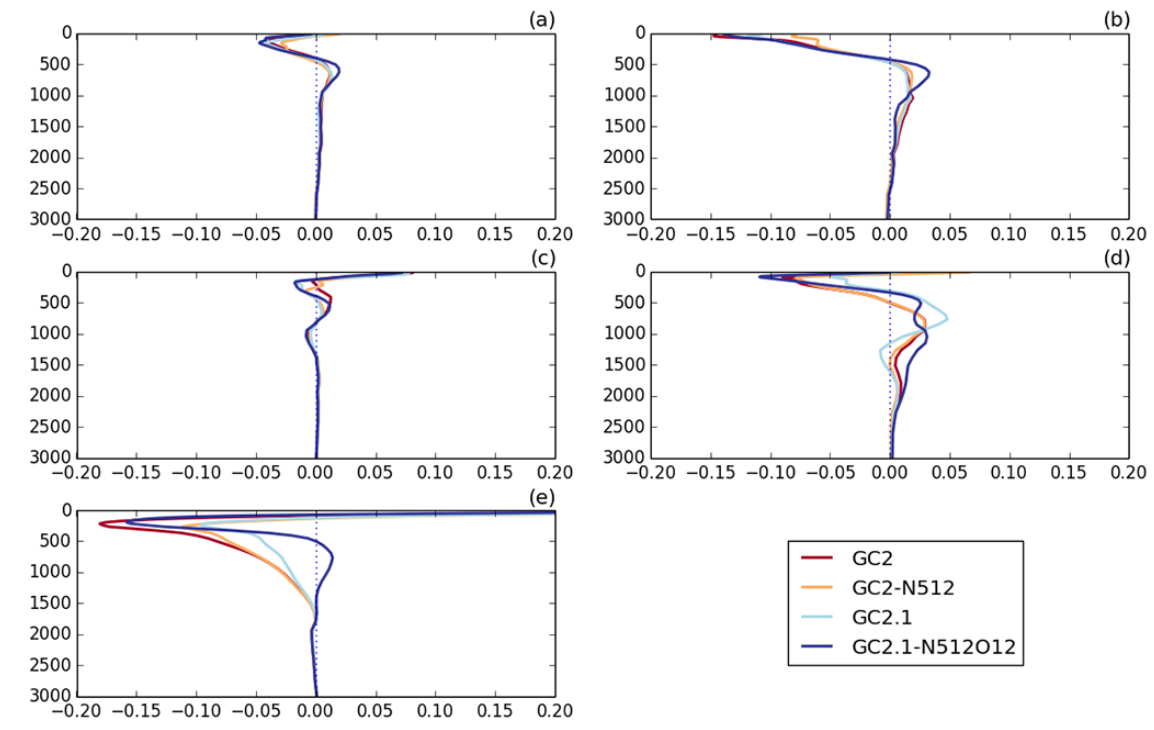

Figure 8. Area-weighted mean salinity difference (years 11-20 minus year 1; psu) for GC2, GC2-N512, GC2.1 and GC2.1-N512O12 for (a) global, (b) $90-30^{\circ} \mathrm{S}$, (c) $30^{\circ} \mathrm{S}-30^{\circ} \mathrm{N}$, (d) $30-90^{\circ} \mathrm{N}$ and (e) $65-90^{\circ} \mathrm{N}$. The vertical axis denotes depth (m).

Jochumsen et al., 2012). This appears to also contribute to a deeper (as well as stronger) NADW outflow in GC2N512O12 (Fig. 10), and we suggest that this is likely to be associated with the increased resolution of the topography in the region of the overflows.

The Antarctic Circumpolar Current (ACC) usually drifts in the ORCA025 GC models from an initial value of approximately 150 to below $100 \mathrm{~Sv}$ (Fig. 11b). Increased ocean resolution counteracts that, with the ACC stabilising close to $130 \mathrm{~Sv}$ in GC2.1-N512O12. This value is close to the obser- vations that suggest an ACC transport of $137 \pm 8 \mathrm{~Sv}$ (Cunningham et al., 2003; Meredith et al., 2011). The reduced drift in the ACC transport can be explained by changes in the density field; the meridional density gradients across the ACC are stronger in GC2.1-N512O12 (with steeper isopycnals) than in GC2. The change in density gradient can be driven by increased convection in polynyas in the Weddell Sea (Hirabara et al., 2012) sending denser water south of the ACC and/or by changes in winds and upwelling of NADW (Allison et al., 2011) sending lighter water north of the ACC. 


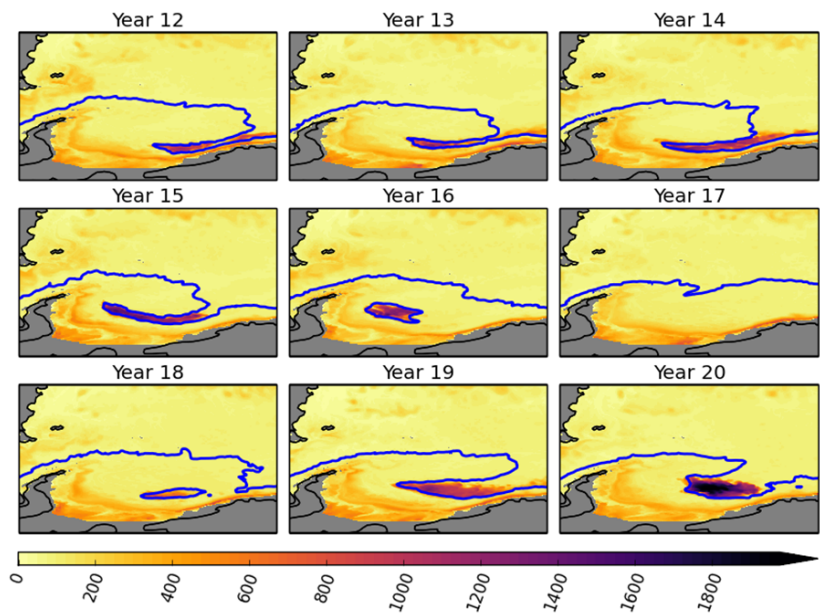

Figure 9. September mixed layer depth $(\mathrm{m})$ and sea ice edge in GC2.1-N512O12 for years 12-20 indicating the presence of a Weddell Sea polynya. The sea ice edge (marked in blue) is based on a threshold of $15 \%$ ice concentration.

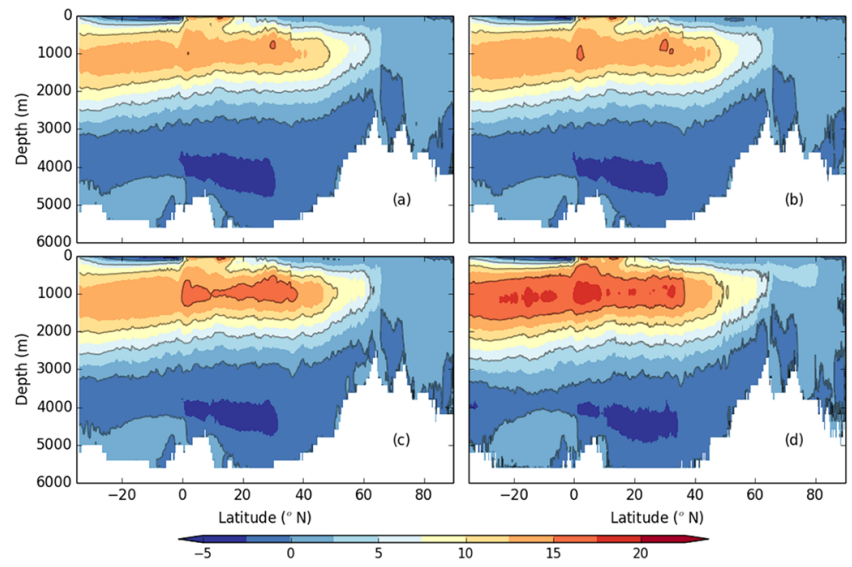

Figure 10. Atlantic Meridional overturning for (a) GC2, (b) GC2N512, (c) GC2.1 and (d) GC2.1-N512O12, the mean over years 1120. Contours in Sverdrups $\left(10^{6} \mathrm{~m}^{3} \mathrm{~s}^{-1}\right)$, with line contour spacing of $5 \mathrm{~Sv}$.

Approximately two-thirds of the difference in density gradient between GC2.1-N512O12 and GC2 is due to the presence of denser water to the south of the ACC in GC2.1N512O12. This is consistent with the polynya formation discussed in the previous section. Future work will look at the robustness of the ACC changes in longer simulations of highresolution models.

\subsection{Heat transport}

As described in Gordon et al. (2000), drifts in volumeaveraged ocean temperature can be related to discrepancies between the actual heat transport by the ocean and the heat
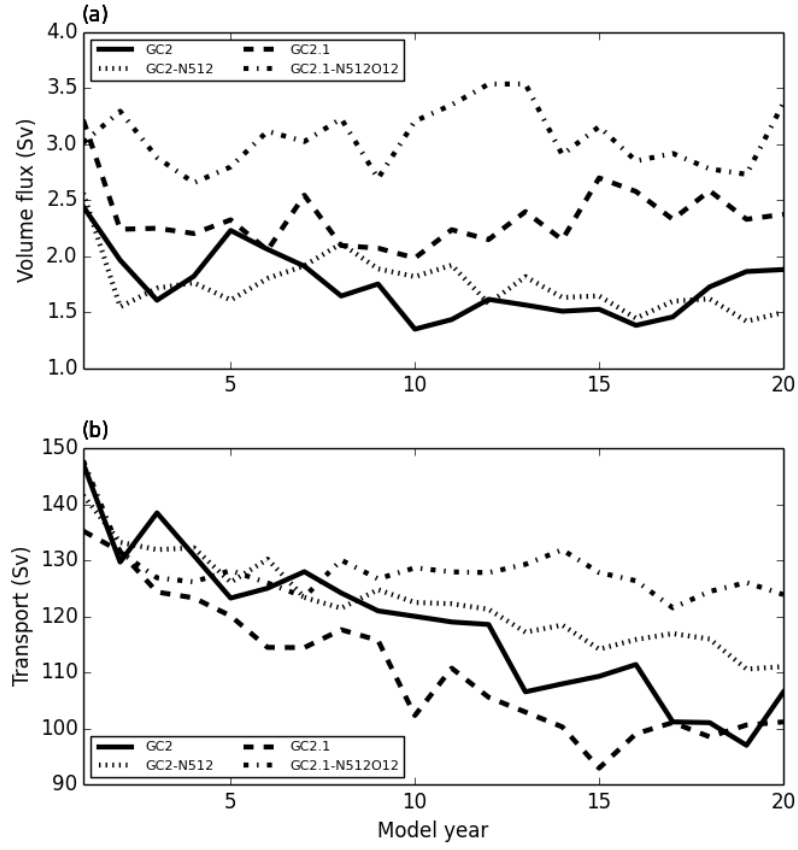

Figure 11. (a) Denmark Strait volume flux (Sv) (calculated as southward flow across the Greenland-Iceland-Scotland ridge below density of $27.8 \mathrm{~kg} \mathrm{~m}^{-3}$ ) and (b) Antarctic Circumpolar Current transport (Sv) from GC2, GC2-N512, GC2.1 and GC2.1N512O12.

transport implied by the surface fluxes; i.e.

$$
\begin{gathered}
\frac{\partial \rho c_{p}<\theta>}{\partial t}+\oint \rho c_{p}\left(\bar{v} \bar{\theta}+\overline{v^{\prime} \theta^{\prime}}\right) \mathrm{d} S \\
+\oint \rho c_{p} A_{\text {iso }} \nabla_{\rho} \theta \mathrm{d} S=\int F \mathrm{~d} A
\end{gathered}
$$

where $\langle\theta\rangle$ is the volume integrated temperature, $\bar{v} \bar{\theta}$ and $\overline{v^{\prime} \theta^{\prime}}$ are the time-mean and time-varying components of the ocean meridional heat transports, $\rho c_{p}$ is density multiplied by specific heat capacity, $A_{\text {iso }}$ is the isoneutral diffusivity, $\nabla_{\rho} \theta$ is the isoneutral gradients of temperature, $F$ is the surface heat flux, $\mathrm{d} S(=\mathrm{d} x \times \mathrm{d} z)$ is the cross-sectional area $(x$ and $z$ denote the zonal and vertical directions) and $\mathrm{d} A$ is the surface area of the region. For our purposes, we make the assumption that the isoneutral fluxes are generally smaller than the other terms (isoneutral diffusive fluxes are very small when integrated over full depth).

Figure 12a shows the global northward heat transport in all four simulations. There are some changes in the Northern Hemisphere in the GC2.1 simulation with the change to hourly coupling, while changes in the Southern Hemisphere are only seen in GC2.1-N512O12, suggesting that these changes are driven by the increase in ocean resolution. The reduction in southward heat transport in GC2.1$\mathrm{N} 512 \mathrm{O} 12$ centred at $45^{\circ} \mathrm{S}$ is highly unusual; although the change does not lie outside interannual variability, a change of this magnitude in the multi-year mean heat transport has 

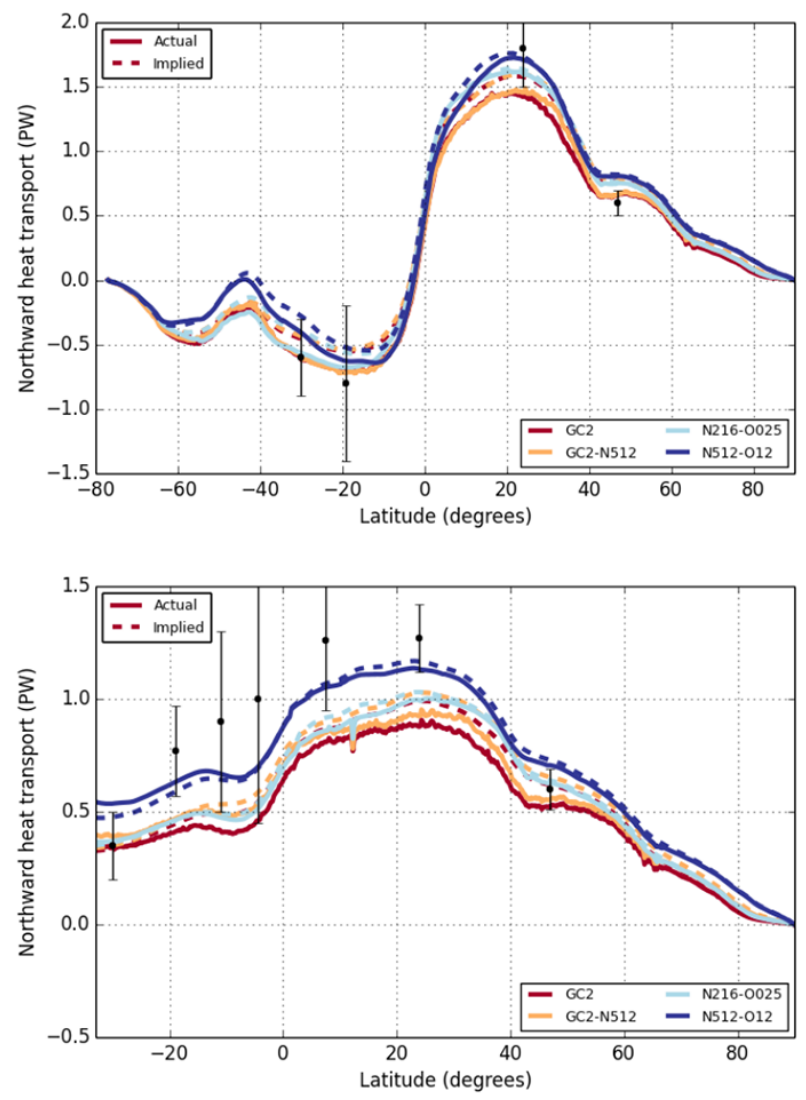

Figure 12. Actual (bold) and implied (dashed) northward heat transports from GC2, GC2-N512, GC2.1 and GC2.1-N512O12 for (a) global and (b) Atlantic basins. The implied transport (integrated southwards from the North Pole using the ocean surface heat flux) uses heat fluxes in which the global mean imbalance has been removed at every point. Observational estimates and associated error bars from Ganachaud and Wunsch (2003) are shown.

not been seen in any other development runs of the GC series. The modelled changes in the heat transports suggest that ocean processes are important in this region, which is particularly relevant given the uncertainty in surface heat fluxes in the Southern Ocean (Cerovecki et al., 2011). The increase in total heat transport comes primarily from the time mean heat transport (not shown). This suggests that increased resolution has either changed the mean circulation or the temperature profile. In contrast, if the increased heat transport was due to the time-varying heat transport, this would imply a direct role for mesoscale eddies. As seen in previous sections, GC2.1-N512O12 shows changes in both the circulation and the temperature profiles. The decreased southward heat transport in the Southern Ocean of GC2.1-N512O12 could - at least partly - explain the reduced warm bias.

By comparing actual ocean heat transports with those implied by surface fluxes (i.e., the second term of the left-hand side of Eq. 1 with the right-hand side of Eq. 1), this gives an indication of the volume-averaged drift in temperature (first term on the left-hand side of Eq. 1). To remove the effect of the net radiative imbalance, the implied ocean heat transport is calculated by subtracting the globally averaged imbalance from the surface fluxes before integrating zonally and meridionally. This is equivalent to removing a globally integrated temperature drift from the left-hand side of Eq. (1). This can be described as

$$
\begin{gathered}
\frac{\partial \rho c_{p}(<\theta>-\bar{\theta})}{\partial t}+\oint \rho c_{p}\left(\bar{v} \bar{\theta}+\overline{v^{\prime} \theta^{\prime}}\right) \mathrm{d} S \\
=\int(F-\bar{F}) \mathrm{d} A,
\end{gathered}
$$

where $\bar{\theta}$ and $\bar{F}$ are the global mean temperature and surface flux respectively. Equation (2) shows that a residual imbalance between the implied and actual ocean heat transports is indicative of local temperature drifts. Both globally and in the Atlantic basin (Fig. 12a, b), GC2.1-N512O12 can be seen to be as close to local balance as any of the other models, suggesting that the net drifts will be of a similar magnitude (in agreement with Fig. 5).

Ocean resolution is the driving factor in a $0.2 \mathrm{PW}$ increase in the northward heat transport in the Atlantic; the modelled heat transports in GC2.1-N512O12 are generally within the error bars of the observations (Ganachaud and Wunsch, 2003; Fig. 12b) in contrast to the other models with the lower resolution ocean component. The change in heat transport is linked to an increase in the overturning circulation (previous section), which is unsurprising given the dominant role of the meridional overturning circulation in the Atlantic heat transport (Hall and Bryden, 1982).

\section{Summary and discussion}

In this paper we have shown results from a coupled climate model with an eddy-resolving $\left(1 / 12^{\circ}\right)$ ocean component coupled to a high-resolution $(25 \mathrm{~km})$ atmosphere component. When the SST bias from this climate simulation is compared to that from the Met Office standard resolution climate model, with eddy-permitting $\left(1 / 4^{\circ}\right)$ ocean component and $60 \mathrm{~km}$ atmosphere component, it is apparent that major SST biases in the Southern Ocean, North Atlantic and North Pacific have been reduced. Comparable experiments increasing only the atmosphere resolution or the coupling frequency, demonstrate that increased ocean resolution is the key driver for this change.

At the enhanced ocean resolution, the ocean circulation leads to increased poleward ocean heat transport in the Northern Hemisphere and reduced poleward ocean heat transport in the Southern Hemisphere. The change in the northward heat transport is driven at least in part by an enhanced NADW cell. The stronger ACC at high resolution may be associated with a number of factors: enhanced windstresses, increased deep water formation in the Weddell Sea 
due to the presence of a polynya, enhanced southward transport of NADW and eddy fluxes. Changes in the global heat transports produce a shift in the large-scale biases, cooling the Southern Ocean and warming the North Atlantic and North Pacific. We have shown that heat penetrates deeper in our $1 / 12^{\circ}$ model; Griffies et al. (2015) demonstrated that mesoscale eddies transport heat upwards, so it is likely that the increased transport of heat to depth is achieved by the time mean as seen in transient experiments such as Banks and Gregory (2006). Future work will be focused on understanding the relative roles of resolving overflow topography (Behrens, 2013), eddy processes within the ocean including compensation and saturation (e.g., Munday et al., 2013) and air-sea interaction on the eddy scale (Roberts et al., 2016) in driving the large-scale changes.

Relative to the recent high-resolution results of Small et al. (2014) and Griffies et al. (2015), our results emphasize the importance of increasing both ocean resolution and coupling frequency. Griffies et al. (2015) showed smaller reductions in SST biases than seen here when moving from $1 / 4$ to $1 / 10^{\circ}$ resolution presumably related to keeping the atmosphere resolution unchanged. Enhanced coupling frequency along with enhanced vertical resolution near the air-sea interface both in the ocean (Megann et al., 2014) and atmosphere (Walters et al., 2016) is one feature of our model set-up that is missing in Small et al. (2014). These aspects of the model set-up may be especially important in regions of strong air-sea interaction including the stratocumulus regions where we see large improvements in the GC2.1-N512O12 simulation. Further work is required to quantify whether high resolution in the atmosphere component is necessary in combination with the high-resolution ocean components and high-frequency coupling to produce the results described in this paper.

As described in Sect. 2, one of the changes to the ocean model at higher resolution was a reduction in the isoneutral diffusivity. Pradal and Gnanadesikan (2014) showed that a reduction in the isoneutral diffusivity from 800 to $400 \mathrm{~m}^{2} \mathrm{~s}^{-1}$ in a coarse-resolution climate model is associated with cooling of the order of $1{ }^{\circ} \mathrm{C}$ at high latitudes after 500 years. Given that the results here exhibit some consistency with those of Pradal and Gnanadesikan (2014) in the Southern Ocean, further work is required to quantify the role of isoneutral diffusivity in producing changes in SST on decadal timescales.

One caveat of these results is that the parallel simulations lasted only 20 years. However, the broad similarity of the results presented here compared with those of Small et al. (2014) from over 100 years of simulation suggest that the results are reasonably robust. In terms of model drift, climate models typically have a fast adjustment within the first 5 years (Sanchez-Gomez et al., 2016). Large adjustments over the first 20 years are generally followed by a multi-centennial drift towards equilibrium between ocean properties and the net TOA flux (Banks et al., 2007). Longer simulations and further analyses will enable the robustness of the results pre- sented here (including wind-SST feedbacks) to be more fully understood.

In the results presented here, the $1 / 12^{\circ}$ ocean model, which has a resolution of approximately $7 \mathrm{~km}$ at mid-latitudes, is coupled to an N512 atmosphere model, which has a resolution of $25 \mathrm{~km}$. The relative importance of the atmosphere and ocean resolutions remains a question, which will continue to be addressed by the community. We suggest that an atmosphere: ocean ratio of $4: 1$ may be too high for the atmosphere to fully respond to the details of the ocean mesoscale. Future work will investigate the impact of coupling to even higher resolution atmosphere models to investigate the role of the atmosphere : ocean ratio.

As we move towards using coupled models for prediction on timescales from days to centuries, the results presented here are highly relevant to prediction up to decadal timescales where data assimilation is employed. A coupled model that more faithfully produces the current state of the ocean will rely less on data assimilation for correcting largescale biases and better represent spatial anomalies that control the large-scale variability. While there are many regions where subsurface drifts are improved at ORCA12 resolution, reducing the drifts seen in mid-depth salinity will be important.

The ocean data assimilation scheme used in Met Office systems is called NEMOVAR, employed in a 3DVar firstguess-at-appropriate-time mode (Waters et al., 2015). A new version of NEMOVAR has recently been developed (Weaver et al., 2016), which uses a 2-D implicit diffusion operator to model the horizontal background error covariances, one of the most computationally expensive aspects of the scheme. This new version has been developed in such a way that the number of costly global communications are minimized and is therefore expected to scale well with resolution. Preliminary implementations of this scheme in the ORCA12 configuration indicate that it will be feasible to implement it for operational ocean forecasting applications.

A key question for these timescales is whether employing enhanced resolution will address the known problem of low signal-to-noise ratios (Eade et al., 2014), which has led to the need for large ensembles for seasonal to decadal forecasting in lower resolution systems. Future work to understand the drivers of large-scale bias reduction will support targeted experiments to address the relative roles of resolution and ensemble size at these timescales. That said, ocean resolution is clearly not going to solve all the issues in climate models; atmosphere errors often dominate surface biases and, even at high resolution, ocean models need improved representation of sub-grid-scale processes.

\section{Code availability}

The MetUM is available for use under licence. A number of research organizations and national meteorologi- 
cal services use the MetUM in collaboration with the Met Office to undertake basic atmospheric process research, produce forecasts, develop the MetUM code and build and evaluate Earth system models. For further information on how to apply for a licence please contact um_collaboration@metoffice.gov.uk. JULES is available under licence free of charge. For further information on how to gain permission to use JULES for research purposes see https://jules.jchmr.org/software-and-documentation. The model code for NEMO v3.4 and v3.5 is available from the NEMO website (http://www.nemo-ocean.eu). On registering, individuals can access the code using the opensource subversion software (http://subversion.apache.org/). The model code for CICE is freely available (http://oceans 11. lanl.gov/trac/CICE/wiki/SourceCode) from the United States
Los Alamos National Laboratory. In order to implement the scientific configuration of GC2/GC2.1 and to allow the components to work together, a number of branches (code changes) are applied to the above codes. Please contact the authors for more information on these branches and how to obtain them.

\section{Data availability}

Due to the size of the model data sets needed for the analysis (temperature, salinity, velocity, sea ice, TOA radiation fluxes and heat transports), they require large storage space of order $1 \mathrm{~TB}$. They can be shared via the STFC-CEDA platform by contacting the authors. 


\section{Appendix A: Model vertical levels}

The sensitivity to vertical resolution is not explored in this paper. However, a reduced description of the vertical levels in GA6 (Table A1) and GO5 (Table A2) are included to allow for comparison with other models. For the full vertical levels, see Walters et al. (2016) and Megann et al. (2014) respectively.

Table A1. Reduced list of levels in GA6, which has 85 vertical levels.

\begin{tabular}{lr}
\hline Level & Rho_height $(\mathrm{m})$ \\
\hline 1 & 10.00 \\
10 & 730.00 \\
20 & 2796.67 \\
30 & 6196.67 \\
40 & 10930.12 \\
50 & 17012.40 \\
60 & 24710.70 \\
70 & 35927.89 \\
80 & 58978.35 \\
85 & 82050.01 \\
\hline
\end{tabular}

Table A2. Reduced list of levels and layer thicknesses in GO5, which has 75 vertical levels.

\begin{tabular}{lrr}
\hline Level & Depth (m) & Thickness (m) \\
\hline 1 & 0.51 & 1.02 \\
10 & 13.99 & 2.37 \\
20 & 61.11 & 7.58 \\
30 & 180.55 & 18.27 \\
40 & 508.64 & 53.76 \\
50 & 1387.38 & 125.29 \\
60 & 2955.57 & 181.33 \\
65 & 3897.98 & 194.29 \\
70 & 4888.07 & 200.97 \\
75 & 5902.06 & 204.23 \\
\hline
\end{tabular}

\section{Appendix B: Model performance and technical aspects}

The GC2.1 configuration was the first in which several further technical components of the coupled system were considered essential to make the simulation manageable. The coupler was upgraded from OASIS3 to OASIS3-MCT (Valcke et al., 2015) in order to improve parallelization of the coupling, particularly given the increased coupling frequency.
ORCA025 files are typically written as one file per processor by standard GC2 configurations and combined into a single file prior to analysis as a post-processing step. However, as HPC parallel file systems are generally tuned for high bandwidth on large files and as GC2.1-N512O12 configurations allocate 50 of the 80 nodes used by the full coupled system to the ocean, this led to performance and functional issues when running on 1600 or more cores. The NEMO XIOS diagnostic server (Madec, 2014) provides an asynchronous I/O (input/output) server capability that allows the diagnostic files to be output as fewer larger files (although the restart files are still written as one file per processor). Its introduction in the model allowed us to overcome the limitations of the file system.

Land suppression was used for the NEMO and CICE models, so that processors are only assigned to regions with active ocean points. This leads to a significant gain in core count, although it meant that the automated large-scale diagnostics usually produced by NEMO (zonal mean heat transports, meridional overturning) could not be generated.

Data volumes from this experiment were particularly large due to the output of additional hourly and 3-hourly fluxes in order to examine the coupling processes in more detail. Each month of model output comprised: ocean monthly mean files (netCDF) of $87 \mathrm{~GB}$ together with $6 \mathrm{~GB}$ of daily files, sea ice output (netCDF) of $57 \mathrm{~GB}$ per month (with an additional 48 GB of hourly output), and atmosphere output (PP format) of $100 \mathrm{~GB}$ per month. In total, the 20 years of simulation produced 85 TB of data.

Little optimization of the model was attempted since GC2.1 is not intended to be supported in the long term. Its successor, GC3, will be used for CMIP6. The GC2.1N512O12 model used 80 full nodes (each of 32 cores) of an IBM Power 7 HPC, of which 55 were allocated to the oceansea ice component (including 5 for the IO servers) and 25 for the atmosphere-land component. The model throughput was 4 months per wall-clock day.

For previous model resolutions, the SCRIP utility (Jones, 1998) was used to generate the conservative remapping files used to regrid coupling data between the ocean and atmosphere grids (for temperature and fluxes), with bilinear interpolation used for the winds and surface currents. However, due to the size of the high-resolution grids used here, and the serial nature of SCRIP, a different method was required. ESMF (ESMF, 2014; a package of parallelized tools that use the same input grid descriptions as SCRIP, but can be run in parallel) was therefore used to generate the remapping weights. 
Acknowledgements. We thank the editor and the two reviewers (Stephen Griffies and Andy Hogg) for their constructive comments. Matt Martin provided useful input on data assimilation for ORCA12. This work was primarily supported by the Joint DECC/Defra Met Office Hadley Centre Climate Programme (GA01101). Part of the work was undertaken with National Capability funding from NERC for ocean modelling. We acknowledge use of the MONSooN system, a collaborative facility supplied under the Met Office-NERC Joint Weather and Climate Research Programme (JWCRP). Malcolm J. Roberts acknowledges support from the EU FP7 IS-ENES2 project for work on ESMF and regridding tools. We acknowledge the considerable effort on development and evaluation of ORCA12 by the DRAKKAR community. Helene T. Hewitt thanks Immy Hewitt.

Edited by: R. Marsh

Reviewed by: S. M. Griffies and A. Hogg

\section{References}

Allison, L. C., Johnson, H. L., and Marshall, D. P.: Spin-up and adjustment of the Antarctic Circumpolar Current and global pycnocline, J. Mar. Res., 69, 167-189, 2011.

Banks, H. T. and Gregory, J. M.: Mechanisms of ocean heat uptake in a coupled climate model and the implications for tracer based predictions of ocean heat uptake, Geophys. Res. Lett., 33, L076208, doi:10.1029/2005GL025352, 2006.

Banks, H. T., Stark, S., and Keen, A. B.: The adjustment of the coupled climate model HadGEM1 towards equilibrium and the impact on global climate, J. Climate, 20, 5815-5826, 2007.

Behrens, E.: The oceanic response to Greenland melting: the effect of increasing model resolution, $\mathrm{PhD}$ thesis, University of Kiel, Germany, 2013.

Best, M. J., Pryor, M., Clark, D. B., Rooney, G. G., Essery, R. L. H., Ménard, C. B., Edwards, J. M., Hendry, M. A., Porson, A., Gedney, N., Mercado, L. M., Sitch, S., Blyth, E., Boucher, O., Cox, P. M., Grimmond, C. S. B., and Harding, R. J.: The Joint UK Land Environment Simulator (JULES), model description Part 1: Energy and water fluxes, Geosci. Model Dev., 4, 677-699, doi:10.5194/gmd-4-677-2011, 2011.

Bodas-Salcedo, A., Williams, K. D., Ringer, M. A., Beau, I., Cole, J. N. S., Dufresne, J.-L., Koshiro, T., Stevens, B., Wang, Z., and Yokohata, T.: Origins of the solar radiation biases over the Southern Ocean in CFMIP2 models, J. Climate, 27, 41-56, doi:10.1175/JCLI-D-13-00169.1., 2014.

Bodas-Salcedo, A., Hill, P. G., Furtado, K., Karmalkar, A., Williams, K. D., Field, P. R., Manners, J. C., Hyder, P., and Kato, S.: Large contribution of supercooled liquid clouds to the solar radiation budget of the Southern Ocean, J. Climate, 29, 42134228, 2016.

Bryan, F. O., Tomas, R., Dennis, J. M., Chelton, D. B., Loeb N. G., and McClean J. L.: Frontal scale air-sea interaction in highresolution coupled climate models, J. Climate, 23, 6277-6291, doi:10.1175/2010JCLI3665.1, 2010.

Cerovecki, I., Talley, L. D., and Mazloff, M. R.: A Comparison of Southern Ocean Air-Sea Buoyancy Flux from an Ocean State Estimate with Five Other Products, J. Climate, 24, 6283-6306, 2011.
Chelton, D. B. and Xie, S.-P.: Coupled ocean-atmosphere interaction at oceanic mesoscales, Oceanography, 23, 52-69, 2010.

Chelton, D. B., Schlax, M. G., and Samelson, R. M.: Global observations of nonlinear mesoscale eddies, Prog. Oceanogr., 91, 167-216, 2011.

Cunningham, S. A., Alderson, S. G., King, B. A., and Brandon, M. A.: Transport and variability of the Antarctic Circumpolar Current in Drake Passage, J. Geophys. Res., 108, 8084, doi:10.1029/2001JC001147, 2003.

Delworth, T. L., Rosati, A., Anderson, W. G., Adcroft, A., Balaji, V., Benson, R., Dixon, K. W., Griffies, S. M., Lee, H.-C., Pacanowski, R. C., Vecchi, G. A., Wittenberg, A. T., Zeng, F., and Zhang, R.: Simulated climate and climate change in the GFDL CM2.5 high-resolution coupled climate model, J. Climate, 25, 2755-2781, doi:10.1175/JCLI-D-11-00316.1, 2012.

Deshayes, J., Treguier, A.-M., Barnier, B., Lecointre, A., Le Sommer, J., Molines, J.-M., Penduff, T., Bourdalle-Badie, R., Drillet, Y., Garric, G., Benshila, R., Madec, G., Biastoch, A., Boening, C. W., Scheinert, M., Coward, A. C., and Hirschi, J. J.: Oceanic hindcast simulations at high resolution suggest that the Atlantic MOC is bistable, Geophys. Res. Lett., 40, 3069-3073, doi:10.1002/grl.50534, 2013.

Dickson, R. R. and Brown, J.: The production of North Atlantic Deep Water: Sources, rates, and pathways, J. Geophys. Res., 99, 12319-12341, doi:10.1029/94jc00530, 1994.

Eade, R., Smith D., Scaife A., Wallace E., Dunstone N., Hermanson L., and Robinson N.: Do seasonal to decadal predictions underestimate the predictability of the real world?, Geophys. Res. Lett., 41, 5620-5628, doi:10.1002/2014GL061146, 2014.

ESMF: Earth System Modelling Framework Reference Manual for Fortran, available at: http://www.earthsystemmodeling.org/ esmf_releases/public/last/ESMF_refdoc (last access: 7 October 2016), 2014.

Frenger, I., Gruber, N., Knutti, R., and Munnich, M.: Imprint of Southern Ocean eddies on winds, clouds and rainfall, Nat. Geosci., 6, 608-612, 2013.

Ganachaud, A. and Wunsch, C.: Large-scale ocean heat and freshwater transports during World Ocean Circulation Experiment, J. Climate, 16, 696-705, 2003.

Gordon C., Cooper, C., Senior, C. A., Banks, H., Gregory, J. M., Johns, T. C., Mitchell, J. F. B., and Wood, R. A.: The simulation of SST, sea ice extents and ocean heat transports in a version of the Hadley Centre coupled model without flux adjustments, Clim. Dynam., 16, 147-168, 2000.

Graham, T., Hermanson, L., Hewitt, H. T., and Storkey, D.: Downstream impacts of biases in North Atlantic overflow water masses in the HadGEM3 climate model, in preparation, 2016.

Griffies, S. M., Winton, M., Anderson, W. G., Benson, R., Delworth, T. L., Dufour, C. O., Dunne, J. P., Goddard, P., Morrison, A. K., Rosati, A., Wittenberg, A. T., Yin, J. J., and Zhang, R.: Impacts on Ocean Heat from Transient Mesoscale Eddies in a Hierarchy of Climate Models, J. Climate, 28, 952-977, 2015.

Hall, M. M. and Bryden, H. L.: Direct estimates and mechanisms of ocean heat transport, Deep-Sea Res., 29, 339-359, 1982.

Hallberg, R.: Using a Resolution Function to Regulate Parameterizations of Oceanic Mesoscale Eddy Effects, Ocean Model., 72, 92-103, doi:10.1016/j.ocemod.2013.08.007, 2013.

Hallberg, R.: Numerical insabilities of the ice/ocean coupled system, CLIVAR Exchanges, 65, 38-42, 2014. 
Hewitt, H. T., Copsey, D., Culverwell, I. D., Harris, C. M., Hill, R. S. R., Keen, A. B., McLaren, A. J., and Hunke, E. C.: Design and implementation of the infrastructure of HadGEM3: the nextgeneration Met Office climate modelling system, Geosci. Model Dev., 4, 223-253, doi:10.5194/gmd-4-223-2011, 2011.

Hirabara, M., Tsujino, H., Nakano, H., and Yamanaka, G.: Formation mechanisms of the Weddell Sea Polynya and the impact on the global abyssal ocean, J. Oceanogr., 68, 771-796, doi:10.1007/s10872-012-0139-3, 2012.

Hunke, E. C. and Lipscomb, W. H.: CICE: the Los Alamos sea ice model documentation and software users' manual, Version 4.1, LA-CC-06-012, Los Alamos National Laboratory, Los Alamos, N. M., USA, 2010.

Hunke, E. C., Lipscomb, W. H., Turner, A. K., Jeffery, N., and Elliott, S.: CICE: The Los Alamos Sea Ice Model, Documentation and Software User's Manual, Version 5.1. Tech. Rep. LA-CC-06012, Los Alamos National Laboratory, Los Alamos, New Mexico, USA, available at: http://oceans11.lanl.gov/trac/CICE (last access: 7 October 2016), 2015.

Hurlburt, H. E., Brassington, G. B., Drillet, Y., Kamachi, M., Benkiran, M., Bourdalle-Badie, R., Chassignet, E. P., Jacobs, G. A., Le Galloudec, O., Lellouche, J. M., Metzger, E. J., Smedstad, O. M., and Wallcraft, A. J.: High-Resolution Global and BasinScale Ocean Analyses and Forecasts, Oceanography, 22, 110 127,2009

Ingleby, B. and Huddleston, M.: Quality control of ocean temperature and salinity profiles - Historical and real-time data, J. Marine Syst., 65, 158-175, 2007.

Jochumsen, K., Quadfasel, D., Valdimarsson, H., and Jonsonn, S.: Variability of the Denmark Strait overflow: Moored timeseries from 1996-2011, J. Geophys. Res., 117, C12003, doi:10.1029/2012JC008244, 2012.

Johns, T. C., Durman, C. F., Banks, H. T., Roberts, M. J., McLaren, A. J., Ridley, J. K., Senior, C. A., Williams, K. D., Jones, A., Rickard, G. J., Cusack, S., Ingram, W. J., Crucifix, M., Sexton, D. M. H., Joshi, M. M., Dong, B. W., Spencer, H., Hill, R. S. R., Gregory, J. M., Keen, A. B., Pardaens, A. K., Lowe, J. A., Boda-Saloedo, A., Stark, S., and Searl, Y.: The new Hadley Centre climate model HadGEM1: Evaluation of coupled simulations in comparison to previous models, J. Climate, 19, 1327-1353, 2006.

Jones P. W.: A User's Guide for SCRIP: A Spherical Remapping and Interpolation Package, Version 1.5, Los Alamos National Laboratory, Los Alamos, USA, 1998.

Macrander, A., Send, U., Valdimarsson, H., Jonsson, S., and Kase, R. H.: Interannual changes in the overflow from the Nordic Seas into the Atlantic Ocean through Denmark Strait, Geophys. Res. Lett., 32, L06606, doi:10.1029/2004gl021463, 2005.

Madec, G.: NEMO ocean engine, Note du Pôle de modélisation, Institut Pierre-Simon Laplace (IPSL), Paris, France, No. 27, ISSN 1288-1619, 2014.

Marzocchi, A., Hirschi, J. J. M., Holliday, N. P., Cunningham, S. A., Blaker, A. T., and Coward, A. C.: The North Atlantic subpolar circulation in an eddy-resolving global ocean model, J. Marine Syst., 142, 126-143, doi:10.1016/j.jmarsys.2014.10.007, 2015.

McClean, J. L., Bader, D. C., Bryan, F. O., Maltrud, M. E., Dennis, J. M., Mirin, A. A., Jones, P. W., Kim, Y. Y., Ivanova, D. P., Vertenstein, M, Boyle, J. S., Jacob, R. L., Norton, N., Craig, A., and Worley, P. H.: A prototype two-decade fully- coupled fine-resolution CCSM simulation, Ocean Model., 39, 10-30, doi:10.1016/j.ocemod.2011.02.011, 2011.

Megann, A., Storkey, D., Aksenov, Y., Alderson, S., Calvert, D., Graham, T., Hyder, P., Siddorn, J., and Sinha, B.: GO5.0: the joint NERC-Met Office NEMO global ocean model for use in coupled and forced applications, Geosci. Model Dev., 7, 10691092, doi:10.5194/gmd-7-1069-2014, 2014.

Meredith, M. P., Woodworth, P. L., Chereskin, T. K., Marshall, D. P., Allison, L. C., Bigg, G. R., Donohue, K., Heywood, K. J., Hughes, C. W., Hibbert, A., Hogg, A. McC., Johnson, H. L., Jullion, L., King, B. A., Leach, H., Lenn, Y.-D., Morales Maqueda, M. A., Munday, D. R., Naveira Garabato, A. C., Provost, C., Sallee J.-B., and Sprintall, J.: Sustained monitoring of the Southern Ocean at Drake Passage: past achievements and future priorities, Rev. Geophys., 49, RG4005, doi:10.1029/2010RG000348, 2011.

Minobe, S., Kuwano-Yoshida, A., Komori, N., Xie, S.-P., and Small, R. J.: Influence of the Gulf Stream on the troposphere, Nature, 452, 206-209, doi:10.1038/nature06690, 2008.

Mizielinski, M. S., Roberts, M. J., Vidale, P. L., Schiemann, R., Demory, M.-E., Strachan, J., Edwards, T., Stephens, A., Lawrence, B. N., Pritchard, M., Chiu, P., Iwi, A., Churchill, J., del Cano Novales, C., Kettleborough, J., Roseblade, W., Selwood, P., Foster, M., Glover, M., and Malcolm, A.: High-resolution global climate modelling: the UPSCALE project, a large-simulation campaign, Geosci. Model Dev., 7, 1629-1640, doi:10.5194/gmd-71629-2014, 2014.

Munday, D. R., Johnson, H. L., and Marshall, D. P.: Eddy saturation of equilibriated circumpolar currents, J. Phys. Oceanogr. 43, 507-532, 2013.

Palmer, M. D. and McNeall, D. J.: Internal variability of Earth's energy budget as simulated by CMIP5 climate models, Environ. Res. Lett., 9, 8 pp., doi:10.1088/1748-9326/9/3/034016, 2014.

Pardaens A. K., Banks, H. T., Gregory, J. M., and Rowntree, P. R.: Freshwater transports in HadCM3, Clim. Dynam., 21, 177-195, 2003.

Pradal, M.-A. and Gnanadesikan, A.: How Does the Redi Parameter for Mesoscale Mixing Impact Global Climate in an Earth System Model?, J. Adv. Model. Earth Syst., 6, 586-601, 2014.

Rae, J. G. L., Hewitt, H. T., Keen, A. B., Ridley, J. K., West, A. E., Harris, C. M., Hunke, E. C., and Walters, D. N.: Development of the Global Sea Ice 6.0 CICE configuration for the Met Office Global Coupled model, Geosci. Model Dev., 8, 2221-2230, doi:10.5194/gmd-8-2221-2015, 2015.

Roberts, M. J., Hewitt, H. T., Hyder, P., Ferreira, D., Josey, S. A., Mizielinski, M., and Shelly, A.: Impact of ocean resolution on coupled air-sea fluxes and large-scale climate, Geophys. Res. Lett., in press, doi:10.1002/2016GL070559, 2016.

Sanchez-Gomez, E., Cassou, C., Ruprich-Robert, Y., Fernandez, E., and Teray, L.: Drift dynamics in a coupled model initialized for decadal forecasts, Clim. Dynam., 46, 1819-1840, doi:10.1007/s00382-015-2678-y, 2016.

Sheldon, L. and Czaja, A.: Seasonal and interannual variability of an index of deep atmospheric convection over western boundary currents, Q. J. Roy. Meteor. Soc., 140, 22-30, doi:10.1002/qj.2103, 2014.

Small, R. J., Bacmeister, J., Bailey, D. A., Baker, A., Bishop, S., Bryan, F. O., Caron, J., Dennis, J., Gent, P. R., Hsu, H.-M., Jochum, M., Lawrence, D. M., Munoz Acevedo, E., diNezio, P., 
Scheitlin, T., Tomas, R., Tribbia, J., Tseng, Y., and Vertenstein, M.: A new synoptic-scale resolving global climate simulation using the Community Earth System Model, J. Adv. Model. Earth Syst., 6, 1065-1094, doi:10.1002/2014MS000363, 2014.

Tréguier, A.-M., Deshayes, J., Lique, C., Dussin, R., and Molines, J.-M.: Eddy contributions to the meridional transport of salt in the North Atlantic, J. Geophys. Res.-Oceans, 117, C05010, doi:10.1029/2012JC007927, 2012.

Valcke, S., Craig, T., and Coquart, L.: OASIS3-MCT User Guide, OASIS3-MCT 3.0, Technical Report, TR/CMGC/15/38, CERFACS/CNRS SUC URA No. 1875, Toulouse, France, 2015.

Vellinga, M. and Wu, P.: Low-Latitude Freshwater Influence on Centennial Variability of the Atlantic Thermohaline Circulation, J. Climate, 17, 4498-4511, doi:10.1175/3219.1, 2004.

Walters, D., Brooks, M., Boutle, I., Melvin, T., Stratton, R., Vosper, S., Wells, H., Williams, K., Wood, N., Allen, T., Bushell, A., Copsey, D., Earnshaw, P., Edwards, J., Gross, M., Hardiman, S., Harris, C., Heming, J., Klingaman, N., Levine, R., Manners, J., Martin, G., Milton, S., Mittermaier, M., Morcrette, C., Riddick, T., Roberts, M., Sanchez, C., Selwood, P., Stirling, A., Smith, C., Suri, D., Tennant, W., Vidale, P. L., Wilkinson, J., Willett, M., Woolnough, S., and Xavier, P.: The Met Office Unified Model Global Atmosphere 6.0/6.1 and JULES Global Land 6.0/6.1 configurations, Geosci. Model Dev. Discuss., doi:10.5194/gmd2016-194, in review, 2016.
Waters, J., Lea, D. J., Martin, M. J., Mirouze, I., Weaver, A., and While, J.: Implementing a variational data assimilation system in an operational 1/4 degree global ocean model, Q. J. Roy. Meteor. Soc., 141, 333-349, doi:10.1002/qj.2388, 2015.

Weaver, A. T., Tshimanga, J., and Piacentini, A.: Correlation operators based on an implicitly formulated diffusion equation solved with the Chebyshev iteration, Q. J. Roy. Meteor. Soc., 142, 455471, doi:10.1002/qj.2664, 2016.

Williams, K. D., Harris, C. M., Bodas-Salcedo, A., Camp, J., Comer, R. E., Copsey, D., Fereday, D., Graham, T., Hill, R., Hinton, T., Hyder, P., Ineson, S., Masato, G., Milton, S. F., Roberts, M. J., Rowell, D. P., Sanchez, C., Shelly, A., Sinha, B., Walters, D. N., West, A., Woollings, T., and Xavier, P. K.: The Met Office Global Coupled model 2.0 (GC2) configuration, Geosci. Model Dev., 8, 1509-1524, doi:10.5194/gmd-8-1509-2015, 2015.

Zhang Y. and Vallis, G. K.: Ocean Heat Uptake in Eddying and NonEddying Ocean Circulation Models in a Warming Climate, J. Phys. Oceanogr., 43, 2211-2229, doi:10.1175/JPO-D-12-078.1, 2013. 